\title{
IMPLEMENTASI GERAKAN LITERASI UNTUK PENANAMAN PENDIDIKAN KARAKTER SISWA SEKOLAH DASAR DI SD NEGERI JAKENAN
}

\author{
Marina Puspita Wati ${ }^{1}$, Sri Surachmi ${ }^{2}$, Sri Utaminingsih ${ }^{3}$ \\ ${ }^{1}$ SDN Jakenan, Pati, Indonesia \\ 2,3 Universitas Muria Kudus, Kudus, Indonesia \\ Imarinapw@yahoo.com, ${ }^{2}$ sri.surachmi@umk.ac.id, ${ }^{3}$ sri.utaminingsih@umk.ac.id
}

\begin{abstract}
ABSTRAK
Penelitian ini bertujuan 1. Mengetahui penerapan gerakan literasi di SD Negeri Jakenan, 2. Mengetahui penanaman karakter sis wa yang terbentuk dalam gerakan literasi di SD Negeri Jakenan, 3. Mengetahui alasan mengapa diadakan gerakan literasi di SD Negeri Jakenan. Jenis penelitian ini adalah penelitian kualitatif. Lokasi penelitian ini di SD Negeri Jakenan Pati. Serta objek yang diteliti adalah perilaku peserta didik SD Negeri Jakenan Pati. Penelitian ini mempunyai hasil yaitu Gerakan literasi sekolah yang bertujuan sebagai penanaman karakter siswa sekolah dasar di SD Negeri Jakenan adalah salah satunya dilakukanya kegiatan pembiasaan membaca sebelum kegiatan belajar mengajar dimulai.Kegiatan ini berlangsung antara 10 sampai 15 menit setiap harinya.Kegiatan ini dikoordinasikan oleh kepala sekolah serta guru .Karakter yang terbentuk dari pelaksanaan kegiatan ini adalah antara lain :tanggung jawab,gemar membaca,menghargai prestasi,rasa ingin tahu,serta religius. Dari penelitian ini disarankan guru menjadi teladan bagi siswa sehingga guru sangat berpengaruh terhadap keberhasilan penanaman karakter kepada siswa. Hendaknya lembaga memberikan perhatian lebih kepada kegiatan literasi dengan lebih banyak lagi menyediakan buku dan program yang mendukung menarik minat siswa untuk membaca.
\end{abstract}

Kata Kunci: implementasi, literasi, pendidikan

\section{IMPLEMENTING LITERATION MOVEMENTS FOR SHAPING THE CHARACTER EDUCATION OF ELEMENTARY SCHOOL STUDENTS IN SD NEGERI JAKENAN}

\begin{abstract}
This study aimed at: 1. Revealing the implementation of the literacy movement at SD Negeri Jakenan, 2. Knowing the instilling of students' characters formed in the literacy movement at SD Negeri Jakenan, 3. Knowing the reasons why the literacy movement was held at SD Negeri Jakenan. This type of research was qualitative research. The setting of this research was SD Negeri Jakenan Pati, and the object was the students' behavior at SD Negeri Jakenan Pati. This research found that the school literacy movement aiming to cultivate the character of elementary school students at SD Negeri Jakenan, one of which was to carry out reading habits before teaching and learning activities began. This activity lasted for between 10 to 15 minutes each day. This activity was coordinated by the principal of the school and teachers. The characters shaped from the implementation of this activity were responsibility, fond of reading, respect for achievement, curiosity, and religion. Based on this research, it was suggested that teachers should be role models for students since teachers were very influential in the success of instilling students' character. Then, the institutions should pay more attention to literacy activities by providing more books and programs that supported students' interest in reading.
\end{abstract}

Keywords: implementation, literacy, education

\begin{tabular}{|c|c|c|}
\hline Submitted & Accepted & Published \\
\hline 20 Oktober 2020 & 05 September 2021 & 18 November 2021 \\
\hline
\end{tabular}

\begin{tabular}{|l|l|r|}
\hline Citation & $:$ & $\begin{array}{r}\text { Wati, M. P., Surachmi, S., \& Utaminingsih, S. (2021). Implementasi Gerakan Literasi Untuk Penanaman Pendidikan } \\
\text { Karakter Siswa Sekolah Dasar Di Sd Negeri Jakenan. Jurnal PAJAR (Pendidikan dan Pengajaran), 5(6), 1528- } \\
\text { 1535. DOI : http://dx.doi.org/10.33578/pjr.v5i6.8190. }\end{array}$ \\
\hline
\end{tabular}

\section{PENDAHULUAN}

Pembangunan karakter bangsa merupakan komitmen kolektif masyarakat Indonesia menghadapi tuntutan global sekarang ini. Sebagai perwujudan dari komitmen tersebut, dibuatlah Undang-Undang Republik Indonesia Nomor 20 Tahun 2003 tentang Sistem Pendidikan Nasional.
Pasal 3 undang-undang tersebut menjelaskan bahwa pendidikan nasional berfungsi mengembangkan kemampuan dan membentuk watak serta peradaban bangsa yang bermartabat dalam rangka mencerdaskan kehidupan bangsa, bertujuan untuk berkembangnya potensi peserta 
didik agar menjadi manusia yang beriman dan bertakwa kepada Tuhan Yang Mahan Esa, berakhlak mulia, sehat, berilmu, cakap, kreatif, mandiri, dan menjadi warga negara yang demokratis serta bertanggung jawab.

Cita-cita luhur bangsa sebagaimana tertuang dalam tujuan pendidikan nasional adalah perwujudan nilai moral bangsa yang harus tertanam dan mengakar dalam pola hidup bangsa, bernegara, dan bermasyarakat. Oleh karena itu, pendidikan karakter bangsa menjadi bagian yang tidak terpisahkan dengan pola pembinaan, baik yang di lakukan dalam rumah tangga, masyarakat, dan sekolah sebagai pionir (Yaumi, 2016:146).

Upaya yang tepat untuk mengubah perilaku peserta didik agar menjadi pribadi yang kuat dan unggul adalah melalui pendidikan.Ini karena pendidikan sangat mempunyai arti yang sangat penting bagi kehidupan manusia. Pendidikan juga merupakan sebagai kekuatan yang juga dapat membantu manusia mencapai kemajuan sebuah peradaban.

Sebagian besar orang Indonesia belum sampai pada tahap menjadikan kegiatan membaca sebagai kebutuhan yang mendasar. Padahal membaca sangat perlu. Dengan membaca seseorang dapat memperluas wawasan dan pandangannya, dapat menambah dan membentuk sikap hidup yang baik, sebagai hiburan serta menambah ilmu pengetahuan, dengan membaca ibarat dapat membuka jendela dunia. Dengan membaca dapat dihindari sikap picik dan fanatisme yang negatif. Dengan demikian kualitas pendidikan di Indonesia masih menghadapi masalah dan bahkan ada indikasi keburaman.

Salah satu faktor yang mempengaruhi rendahnya minat baca ini adalah terbatasnya jumlah perpustakaan sekolah. Dari dua ratus ribu sekolah dasar di Indonesia cuma dua puluh ribu yang memiliki perpustakaan standar. Dapat disimpulkan bahwa perpustakaan sekolah selama ini belum dijadikan sebagai salah satu hal yang penting dalam meningkatkan mutu pendidikan. Pengelolaan perpustakaan sekolah masih tertumpu pada anggaran yang diberikan oleh pemerintah. Untuk mengatasi masalah ini, perlu mengembangkan perpustakaan sekolah berbasis siwa. Sehingga siswa dapat melaksanakan gerakan literasi (Yaumi, 2016:155-156).

Hasil observasi dan wawancara di SD Negeri Jakenan pendidikan karakter siswa belum sepenuhnya terlaksana dengan baik. Hal tersebut dapat dilihat dari tingkah laku siswa seperti melawan kepada guru, mengganggu temannya, berbohong, dan menyontek ketika diadakan tes.

Dari hasil observasi dan wawancara peneliti tertarik untuk melakukan penelitian dengan judul "Implementasi Gerakan Literasi Untuk Penanaman Pendidikan Karakter Siswa Sekolah Dasar di SD Negeri Jakenan" agar siswa memiliki karakter yang positif.

\section{KAJIAN TEORETIS Pengertian Literasi}

Menurut Merriam-Webster (2013:34) Literasi merupakan kualitas atau kemampuan melek huruf atau aksara yang didalamnya meliputi kemampuan membaca dan menulis. Namun lebih dari itu, makna literasi juga mencakup melek visual yang artinya kemampuan untuk mengenali dan memahami ide-ide yang disampaikan secara visual.

Menurut Unesco pemahaman orang tentang makna literasi sangat dipengaruhi oleh penelitian akademik, institusi, konteks nasional, nilai-nilai bidaya, dan juga pengalaman. Pemahaman yang paling umum dari literasi adalah seperangkat keterampilan nyata khususnya keterampilan kognitif membaca dan menulis yang terlepas dari konteks dimana keterampilan itu diperoleh dan dari siapa memperolehnya.

Dari pendapat diatas dapat peneliti simpulkan bahwa literasi adalah kualitas atau kemampuan kognitif membaca dan menulis.

\section{Pengertian Karakter}

Menurut Parwez dalam Yaumi (2016:7-8) menjelaskan beberapa definisi pendidikan karakter yang disimpulkan dari sekian banyak definisi yang dipahami oleh para penulis barat dewasa ini. Definisi tersebut dapat dijabarkan sebagai berikut:

1. Moralitas adalah karakter.Karakter merupakan sesuatu yang terukir dalam diri seseorang.Karakter merupakan kekuatan batin.Pelanggaran susila (amoralitas)juga 
merupakan karakter,tetapi untuk menjadi bermoral dan tidak bermoral adalah sesuatu yang ambigu.

2. Karakter adalah manifestasi kebenaran dan kebenaran adalah penyesuaian kemunculan pada realitas.

3. Karakter adalah mengadopsi kebaikan dan kebaikan adalah gerakan menuju suatu tempat kediaman.Kejahatan adalah perasaan gelisah yang tiada berujung dari potensialitas manusia tanpa sesuatu yang dapat dicapai, jika tidak mengambil arah namun tetap juga terjebak dalam ketidak tahuan,dan akhirnya semua sirna.

4. Karakter adalah memiliki kekuatan terhadap diri sendiri, karakter adalah kemenangan dari penghambaan terhadap diri sendiri.

5. Dalam pengertian yang lebih umum, karakter adalah sikap manusia terhadap lingkunganya yang diekspresikan dalam tindakan.

Dari kelima definisi karakter sebagaimana dijabarkan diatas,maka dapat dikatakan bahwa karakter adalah moralitas kebenaran ,kebaikan kekuatan dan sikap seseorang yang ditunjukkan kepada orang lain melalui tindakan.

\section{Indikator Keberhasilan Pendidikan Karakter}

Keberhasilan program pendidikan karakter dapat diketahui dari perwujudan indikator Standar Kompetensi Lulusan dalam pribadi peserta didik secara utuh karena hasil pendidikan sebagai output dari setiap satuan pendidikan belum menunjukkkan keutuhan tersebut. Bahkan dapat dikatakan bahwa lulusan-lulusan dari setiap satuan pendidikan tersebut baru menunjukkan SKL pada permukaan saja, atau hanya kulitnya saja. Kondisi ini juga boleh jadi disebabkan karena alat ukur atau penilaian keberhasilan peserta didik dari setiap satuan pendidikan hanya menilai permukaannya saja, sehingga hasil penilaian tersebut belum menggambarkan kondisi yang sebenarnya.

Keberhasilan pendidikan tersebut misalnya dapat dilihat dalam setiap rumusan SKL. Sebagai contoh SKL adalah sebagai berikut:

1. Mengamalkan ajaran agama yang dianut sesuai dengan tahap perkembangan anak.

2. Memahami kekurangan dan kelebihan diri sendiri.

3. Menunjukkan sikap percaya diri.
4. Mematuhi aturan-aturan sosial yang berlaku dalam lingkungan yang luas.

5. Menghargai keberagaman agama, budaya, suku, ras, dan golongan sosial ekonomi dalam lingkungan nasional.

6. Mencari dan menerapkan informasi dari lingkungan sekitar dan sumber-sumber lain secara logis, kritis, dan kreatif.

7. Menunjukkan kemampuan berfikir logis, kritis, kreatif, dan inovatif.

8. Menunjukkan kemampuan belajar secara mandiri sesuai dengan potensi yang dimilikinya.

9. Menunjukkan kemampuan menganalisis dan memecahkan masalah dalam kehidupan seharihari,

10.Mendeskripsikan gejala alam dan sosial.

Selain itu, indikator keberhasilan program pendidikan karakter di sekolah dapat diketahui dari berbagai perilaku sehari-hari yang tampak dalam setiap aktivitas sebagai berikut.

1. Kesadaran

2. Kejujuran

3. Keikhlasan

4. Kesederhanaan

5. Kemandirian

6. Kepedulian

7. Kebebasan dalam bertindak

8. Kecermatan/ketelitian

9. Komitmen

Apa yang diungkapkan diatas harus menjadi milik seluruh warga sekolah. Untuk kepentingan tersebut, guru, kepala sekolah, pengawas, bahkan komite sekolah harus memberi contoh dan menjadi suri tauladan dalam mempraktikkan indikator-indikator pendidikan karakter dalam perilaku sehari-hari. Dengan demikian, akan tercipta iklim yang kndusif bagi pembentukan karakter peserta didik, dan seluruh warga sekolah sehingga pendidikan karakter tidak hanya dijadikan ajang pembelajaran, tetapi menjadi tanggung jawab semua warga sekolah untuk membina dan mengembangkannya (Mulyasa, 2012: 11-12).

\section{METODE PENELITIAN}

Peneliti di dalam melakukan penelitian menggunakan pendekatan kualitatif. Alasanya 
penggunaan penelitian kualitatif adalah peneliti merasa pendekatan yang cocok untuk digunakan dalam meneliti implementasi nilai karakter pada peserta didik adalah metode kualitatif.Ini dikarenakan oleh hubungan dengan tingkah laku peserta didik satu sama lain. Lokasi penelitian adalah di SD Negeri Jakenan Pati.Sedangkan waktu pelaksanaanya adalah setiap hari di saat sebelum masuk,ini dimaksudkan agar peneliti lebih mudah untuk mengamati perilaku peserta didik.

Adapun jenis data yang digunakan didalam penelitian ini adalah data kualitatif. Sumber data penelitian ini menggunakan dua sumber data yaitu data primer melalui kegiatan mengamati kepala sekolah, guru, tenaga kependidikan, peserta didik, serta petugas kebersihan yang ada di SD Negeri Jakenan. Sedangkan data sekunder didapatkan penelliti adalah sumber data penunjang atau sumber data pendukung didalam penelitian.Ini didapatlan dari komentar masyarakat sekitar sekolah serta adanya data atau dokumen yang dimiliki oleh sekolah.

Teknik pengumpulan data dilakukan melalui observasi, wawancara, dan dokumentasi. Teknik analisis data menggunakan analisis deskriptif kualitatif. Keabsaha data dilakukan dengan pemeriksaan kriteria: derajat kepercayaan, keteralihan, kebergantungan, dan kepastian.

\section{HASIL DAN PEMBAHASAN}

\section{Sejarah singkat SD Negeri Jakenan}

SD Negeri Jakenan adalah satu-satunya sekolah dasar negeri di desa Jakenan. SD Negeri Jakenan didirikan pada tahun 1912 yang dahulu didirikan oleh Belanda. Sekolah ini dahlunya merupakan sekolah rakyat.Sekolah ini juga mempunyai ciri khas yaitu bangunan utama yang masih terbuat dai kayu untuk mempertahankan keaslianya dari tahun 1912. SD Negeri Jakenan merupakan satu-satunya sekolah bertingkat di kecamatan Jakenan. SD ini juga merupakan sekolah regruping yang awalnya adalah SD Negeri 01 Jakenan dan SD Negeri 02 Jakenan yang mengalami penggabungan yang dikarenakan banyak sebab diantaranya adalah karena jumlah murid dari tahun ke tahun yang semakin berkurang SD Negeri 02 Jakenan.Terletak di Jln Jakenan Jakenan Km 01 Jakenan.
SD Negeri Jakenan memiliki 1 orang kepala sekolah, jumlah guru sebanyak 17,1 orang tenaga perpustakaan, dan 1 orang penjaga sekolah. Di SD Jakenan memiliki 11 ruang kelas, 1 ruang laboratorium, 1 gudang, 1 ruang serbaguna, 1 gedung perpustakaan, 1 dapur, 1 mushola, 7 kamar mandi/wc siswa, dan 1 kamar mandi/wc guru.

Di SD Negeri Jakenan memiliki beberapa ekstrakurikuler. Ada yang bersifat wajib serta ada yang bersifat pilihan. Ekstrakurikuler wajib adalah pramuka dan BTQ. Sedangkan ekstrakurikuler pilihan adalah seni tari, pecinta lingkungan, polcil, karate, taekwondo, silat, sepak takraw, sepakbola, serta reporter cilik. Berbagai prestasi mulai akademik hingga non akademikpun sudah diraih oleh SD ini.

\section{Penanaman Pendidikan Karakter di SD Negeri Jakenan}

Program pendidikan karakter di SD Negeri Jakenan dilakukan dengan berbagai macam kegiatan diantaranya adalah kegiatas dalam pembiasaan maupun non pembiasaan. Kegiatan tersebut adalah sebagai berikut:

1. Kegiatan pembiasaan setiap pagi sebelum kegiatan belajar mengajar dimulai yaitu membaca Asmaul Husna.

2. Kegiatan pembiasaan shalat dhuhur berjamaah secara bergilir sesuai jadwal yang telah ditentukan sekolah.

3. Kegiatan pembiasaan sholat dhuha berjamaah yang dilakukan oleh kelas tinggi yaitu kelas empat, lima, dan enam.

4. Kegiatan jumat sehat secara rutin yang dilakukan setiap hari jumat.

5. Pelaksanaan kegiatan literasi yaitu kegiatan membaca yang dilakukan setelah berbaris didepan kelas

6 Mengambil sampah minimal 5 sampah yang berada di ruang kelas sewaktu akan pulang.

\section{Pelaksanaan Gerakan Literasi Sekolah di SD Negeri Jakenan}

Kegiatan gerakan literasi di SD Negeri Jakenan meliputi kegiatasn pembiasaan (membaca dalam hati dan membaca nyaring), kegiatan pengembangan (mengenal isi cerita, membuat ringkasan cerita, dan kegiatan seni peran), dan 
kegiatan pembelajaran berbasis literasi.

Pelaksanaan gerakan literasi di SD Negeri Jakenan dalam kegiatan pembiasaan membaca dalam hati dengan tujuan untuk membangun kebiasaan membaca dengan sasaran siswa-siswi kelas I sampai kelas VI yaitu dilaksanakan meliputi kegiatan sebagai berikut:

1. Siswa-siswi membaca dalam hati dari buku yang telah dipilih sesuai keinginannya.

2. Bapak/Ibu guru memberikan contoh membaca dalam hati

3. Siswa-siswi memilih salah satu buku

4. Siswa bersama guru membuat kesepakatan waktu memualai dan berakhirnya kegiatan membaca

5. Guru tidak memberikan tugas akademik yang perlu dilaporkan.

6. Seluruh warga sekolah ikut berpartisipasi

Pelaksanaan gerakan literasi di SD Negeri Jakenan dalam kegiatan pembiasaan membaca nyaring dengan tujuan untuk membangkitkan minat baca peserta didik, meningkatkan pengetahuan kepada anak, dan mendorong anak untuk aktif dalam pembelajaran dengan sasaran siswa kelas IV sampai kelas VI yaitu dilaksanakan meliputi kegiatan sebagai berikut:

1. Siswa dan guru menentukan bacaan yang dipilh

2. Guru memberikan contoh membaca materi bacaan terlebih dahulu

3. Mengidentifikasi proses dan strategi yang akan digunakan

4. Guru perlu mengantisipasi di bagian mana dalam bacaan " pengetahuan dasar" perlu dibangun

5. Pada tahap sebelum membaca, guru memilih buku/cerita yang bermanfaat untuk dibacakan karena memiliki kandungan nialai moral yang dapat membentuk karakter siswa

6. Guru tidak membaca terlalu cepat dan menggunakan suara yang berbeda untuk pelaku yang berbeda

7. Siswa disarankan membaca cerita menarik lain di hadapan teman sekelas ataupun diadakan kompetisi lomba membaca cerita untuk kegiatan pembiasaan budaya membaca.

Pelaksanaan pengembangan gerakan literasi di SD Negeri Jakenan dalam kegiatan untuk mengenal isi elemen-elemen cerita, membuat jurnal tanggapan terhadap cerita, dan kegiatan seni peran berbasis tanggapan terhadap cerita dengan tujuan untuk meningkatkan kemampuan siswa dalam menganalisis cerita dengan sasaran siswa kelas tinggi yaitu

dilaksanakan meliputi kegiatan sebagi berikut:

1. Siswa memilih satu buku selama waktu yang di tetapkan (5-10 menit)

2. Guru bersama siswa membuat kesepakatan kapan waktu berakhirnya

3. Guru memberi tagihan berupa jurnal tanggapan terhadap siswa

4. Semua warga sekolah ikut berpartisipasi.

Pelaksanaan gerakan literasi di SD Negeri

Jakenan dalam pembelajaran berbasis literasi dengan tujuan untuk menumbuhkan semangat rasa ingin tahu dengan sasaran kelas IV sampai kelas VI yaitu dilaksanakan meliputi kegiatan sebagai berikut:

1. Guru mencari referensi pembelajaran yang relevan dan mengurangi ketergantungan kepada buku teks pelajaran

2. Siswa membaca teks yang telah disediakan guru

3. Memberi tagihan sesuai dengan lembar kerja yang disiapkan guru

4. Siswa mempersentasikan hasil pekerjaannya

5. Membuat simpulan dan pemajangan.

\section{Karakter Siswa di SD Negeri Jakenan}

Dalam implementasi gerakan literasi di SD Negeri Jakenan karakter siswa yang terbentuk adalah:

1. Karakter Religius

Siswa di SD Negeri Jakenan memiliki karakter nilai religius dapat dilihat dalam kegiatan pembiasaan siswa membaca Asmaul Husna setiap pagi sebelum kegiatan pembelajaran dimulai. Karakter religius siswa SD Negeri Jakenan juga ditunjukkan dalam pembiasaan berdoal sebelum dan sesudah belajar selain itu juga mengucapkan salam kepada bapak/ibu guru dan temannya ketika bertemu.

2. Karakter Rasa Ingin Tahu

Siswa di SD Negeri Jakenan memiliki karakter rasa ingin tahu dapat dilihat dalam kegiatan pembelajaran berbasis literasi yang 
menunjukkan siswa selalu bertanya mengenai buku isi buku teks yang telah di bacanya. Buku yang di baca siswa dalam penerapan gerakan literasi di SD Negeri Jakenan tidak hanya satu buku yang di baca oleh siswa sehingga dengan membaca buku semakin banyak maka timbul rasa ingin tahu siswa yang lebih besar.

3. Karakter gemar membaca

Siswa di SD Negeri Jakenan memiliki karakter gemar membaca dapat dilihat dalam kegiatan pembiasaan siswa membaca buku setiap pagi sebelum kegiatan pembelajaran dimulai. Kegiatan gemar membaca juga didukung dengan adanya gedung perpustakaan SD Negeri Jakenan dengan berbagai jenis buku referensi yang menarik siswa untuk gemar membaca dengan ruangan perpustakaan yang nyaman untuk membaca buku.

4. Karakter Menghargai Prestasi

Siswa di SD Negeri Jakenan memiliki karakter menghargai prestasi dapat di tunjukkan ketika siswa dalam kegiatan berbasis literasi dan diminta untuk mempresentasikan pekerjaannya dengan tepat siswa lain memberikan tepuk tangan atau apresiasi dengan pemajangan hasil karya siswa.

5. Karakter Tanggung Jawab

Siswa di SD Negeri Jakenan memiliki karakter tanggung jawab dapat di tunjukkan ketika siswa pembelajaran berbasis literasi guru memberikan tugas dan siswa dapat memenuhi tanggung jawabnya dengan menyelesaikan tugas yang di berikan guru dengan tepat waktu. Hal lain di tunjukkan siswa berkaitan dengan karakter tanggung jawab yaitu pinjam buku perpustakaan dengan merawat buku yang telah dipinjamkan dan mengembalikannya dengan tepat waktu.

\section{Kendala Gerakan Literasi dalam Penanaman Pendidikan Karakter di SD Negeri Jakenan}

Dalam implementasi gerakan literasi di SD Negeri Jakenan masih banyak kendala yang melaksanakannya. Kendala tersebut berasal dari faktor dalam siswa maupun faktor luar siswa. Kendala yang berasal dari siswa sendiri yaitu masih adanya siswa yang belum bisa membaca. Siswa yang belum bisa membaca kebanyakan berasal dari kelas 1 dan kelas 2 SD Negeri Jakenan.

Selain faktor dari siswa sendiri juga mengalami kendala dari luar siswa yaitu peran orang tua yang masih minim untuk memberikan motivasi serta dukungan terhadap anaknya untuk dilaksanakan meliputi kegiatan sebagi berikut:

1. Siswa memilih satu buku selama waktu yang di tetapkan (5-10 menit)

2. Guru bersama siswa membuat kesepakatan kapan waktu berakhirnya

3. Guru memberi tagihan berupa jurnal tanggapan terhadap siswa

4. Semua warga sekolah ikut berpartisipasi.

Pelaksanaan gerakan literasi di SD Negeri

Jakenan dalam pembelajaran berbasis literasi dengan tujuan untuk menumbuhkan semangat rasa ingin tahu dengan sasaran kelas IV sampai kelas VI yaitu dilaksanakan meliputi kegiatan sebagai berikut:

1. Guru mencari referensi pembelajaran yang relevan dan mengurangi ketergantungan kepada buku teks pelajaran

2. Siswa membaca teks yang telah disediakan guru

3. Memberi tagihan sesuai dengan lembar kerja yang disiapkan guru

4. Siswa mempersentasikan hasil pekerjaannya

5. Membuat simpulan dan pemajangan.

\section{Karakter Siswa di SD Negeri Jakenan}

Dalam implementasi gerakan literasi di SD Negeri Jakenan karakter siswa yang terbentuk adalah:

1. Karakter Religius

Siswa di SD Negeri Jakenan memiliki karakter nilai religius dapat dilihat dalam kegiatan pembiasaan siswa membaca Asmaul Husna setiap pagi sebelum kegiatan pembelajaran dimulai. Karakter religius siswa SD Negeri Jakenan juga ditunjukkan dalam pembiasaan berdoal sebelum dan sesudah belajar selain itu juga mengucapkan salam kepada bapak/ibu guru dan temannya ketika bertemu.

2. Karakter Rasa Ingin Tahu

Siswa di SD Negeri Jakenan memiliki karakter rasa ingin tahu dapat dilihat dalam kegiatan pembelajaran berbasis literasi yang 
menunjukkan siswa selalu bertanya mengenai buku isi buku teks yang telah di bacanya. Buku yang di baca siswa dalam penerapan gerakan literasi di SD Negeri Jakenan tidak hanya satu buku yang di baca oleh siswa sehingga dengan membaca buku semakin banyak maka timbul rasa ingin tahu siswa yang lebih besar.

3. Karakter gemar membaca

Siswa di SD Negeri Jakenan memiliki karakter gemar membaca dapat dilihat dalam kegiatan pembiasaan siswa membaca buku setiap pagi sebelum kegiatan pembelajaran dimulai. Kegiatan gemar membaca juga didukung dengan adanya gedung perpustakaan SD Negeri Jakenan dengan berbagai jenis buku referensi yang menarik siswa untuk gemar membaca dengan ruangan perpustakaan yang nyaman untuk membaca buku.

4. Karakter Menghargai Prestasi

Siswa di SD Negeri Jakenan memiliki karakter menghargai prestasi dapat di tunjukkan ketika siswa dalam kegiatan berbasis literasi dan diminta untuk mempresentasikan pekerjaannya dengan tepat siswa lain memberikan tepuk tangan atau apresiasi dengan pemajangan hasil karya siswa.

5. Karakter Tanggung Jawab

Siswa di SD Negeri Jakenan memiliki karakter tanggung jawab dapat di tunjukkan ketika siswa pembelajaran berbasis literasi guru memberikan tugas dan siswa dapat memenuhi tanggung jawabnya dengan menyelesaikan tugas yang di berikan guru dengan tepat waktu. Hal lain di tunjukkan siswa berkaitan dengan karakter tanggung jawab yaitu pinjam buku perpustakaan dengan merawat buku yang telah dipinjamkan dan mengembalikannya dengan tepat waktu.

\section{Kendala Gerakan Literasi dalam Penanaman Pendidikan Karakter di SD Negeri Jakenan}

Dalam implementasi gerakan literasi di SD Negeri Jakenan masih banyak kendala yang melaksanakannya. Kendala tersebut berasal dari faktor dalam siswa maupun faktor luar siswa. Kendala yang berasal dari siswa sendiri yaitu masih adanya siswa yang belum bisa membaca. Siswa yang belum bisa membaca kebanyakan berasal dari kelas 1 dan kelas 2 SD Negeri Jakenan.

Selain faktor dari siswa sendiri juga mengalami kendala dari luar siswa yaitu peran orang tua yang masih minim untuk memberikan motivasi serta dukungan terhadap anaknya untuk melalakukan kegiatan gemar membaca dengan memfasilitasi buku-buku bacaan di rumah. Keterbatasan buku bacaan yang ada di sekolah karena kurangnya sumber dana untuk menambah jumlah referensi buku bacaan juga menjadi kendala dalam implementasi gerakan literasi di SD Negeri Jakenan.

\section{SIMPULAN DAN REKOMENDASI}

Implementasi gerakan literasi di SD Negeri Jakenan dilakukan dengan kegiatan pembiasaan,dan penanaman pendidikan karakter berbasis literasi. Kegiatan pembiasaan dilakukan dengan cara membaca dalam hati dan membaca nyaring. Kegiatan pembiasaan dilakukan dengan cara mencari isi cerita, membuat tanggapan cerita, dan melakukan seni peran dari tanggapan. Kegiatan pembelajaran dilakukan dengan memberikan pembelajaran berbasis literasi. Denngan adanya gerakan literasi di SD Negeri 2 Jakenan dapat membentuk karakter siswa. Karakter siswa SD Negeri Jakenan yang terbentuk yaitu: religius, rasa ingin tahu, gemar membaca, tanggung jawab, dan menghargai prestasi. Alasan diadakannya gerakan literasi di SD Negeri Jakenan agar dapat membentuk karakter siswa yang lebih positif.

Saran dalam penelitian ini yaitu: bagi kepala sekolah di sarankan untuk menambah buku referensi yang ada di sekolah dan memberikan fasilitas ruang baca yang memadai untuk banyak siswa, bagi guru disarankan untuk memberikan contoh pembiasaan membaca buku setiap hari di sekolah dan dapat mengarahkan pembentukan karakter peserta didik dari buku yang telah di baca, dan bagi peserta didik menjadi manusia yang berguna dan dapat menjalankan serta memiliki kebiasaan membca didalam kehidupan sehai-hari serta mampu mengaplikasikan budi pekerti yang terkandung didlam kegiatan membaca. 


\section{DAFTAR PUSTAKA}

Abdul, M., \& Andayani, D. (2011). Pendidikan Karkter Prespektif Islam. Bandung : Rosda Karya.

Fajarwati. (2017). Implementasi Program Literasi Sekolah Di Kelas Rendah SD Ngoto Sewon Bantul. Bandung: Bumi Aksara.

Farida, R. (2012). Pengajaran Membaca di Sekolah Dasar. Jakarta: Bumi Aksara.

Hilal. (2018). Gerakan Literasi Sekolah di Sekolah Dasar. Jurnal Pendidikan dan Pengembangan, 3(4), 811-812.

Kesuma, D., Cepi, T., \& Johar, P. (2011). Pendidikan Karakter: Kajian Teori dan Praktik di Sekolah. Bandung: PT Remaja Rosdakarya.

Lickona, T. (2012). Mendidik Untuk Membentuk Karakter. Jakarta: Bumi Aksara.

Lickona, T. (2012). Persoalan Karakter. Jakarta: Bumi Aksara.

Majid, A. (2013). Pendidikan Karakter Perspektif Islam. Bandung: PT Remaja Rosdakarya.

Megawangi, R. (2014). Pendidikan Karakter Solusi Yang Tepat Untuk Membangun Bangsa. Jakarta: Star Energy

Mu'in, Fatchul. (2011). Pendidikan Karakter: Konstruksi Teoritik \& Praktik. Yogyakarta: Ar-Ruzz Media

Mulyasa. (2012). Manajemen Pendidikan Karakter. Jakarta: PT. Bumi Aksara.

Muslich, M. (2013). Pendidikan Karakter Menjawab Tantangan Krisis Multidimensional. Jakarta: PT Bumi Aksara.

Webster, M. (2013). Webster's Ninth New Collagiate Dictionary, Merriam Webster Inc.

Yaumi, M. (2016). Pendidikan Karakter Landasan, Pilar, dan Implementasi. Jakarta: Prenadamedia Group.

Zubaedi. (2012). Desain Pendidikan Karakter. Jakarta: Kencana Prenada Media Group. 